\title{
INTEGRATED ASSESSMENT OF IMPACT OF WATER RESOURCES OF IMPORTANT RIVER BASINS IN EASTERN INDIA UNDER PROJECTED CLIMATE CONDITIONS
}

\author{
ROY P.K. ${ }^{1, *}$ \\ SAMAL N.R. ${ }^{2}$ \\ ROY M.B. ${ }^{3}$ \\ MAZUMDAR A. ${ }^{4}$
}

\author{
${ }^{1}$ School of Water Resources Engineering, Jadavpur University \\ Kolkata, West Bengal, India \\ ${ }^{2}$ Institute for Sustainable Cities \\ City University of New York, New York, USA \\ ${ }^{3}$ Department of Geography, GCBT College \\ Habra, West Bengal, India \\ ${ }^{4}$ School of Water Resources Engineering, Jadavpur University \\ Kolkata, West Bengal, India
}

Received: 24/04/2015

Accepted: 20/07/2015

Available online: 27/08/2015 *to whom all correspondence should be addressed: e-mail: pk1roy@yahoo.co.in

\section{ABSTRACT}

The impact of climate change on water resources through increased evaporation combined with regional changes in precipitation characteristics has the potential to affect mean runoff, frequency and intensity of floods and droughts, soil moisture and water supply for irrigation and hydroelectric power generation. The Ganga-Brahmaputra-Meghna (GBM) system is the largest in India with a catchment area of about 110Mha, which is more than $43 \%$ of the cumulative catchment area of all the major rivers in the country. The river Damodar is an important sub catchment of GBM basin and its three tributaries- the Bokaro, the Konar and the Barakar form one important tributary of the Bhagirathi-Hughli (a tributary of Ganga) in its lower reaches. The present study is an attempt to assess the impacts of climate change on water resources of the four important Eastern River Basins namely Damodar, Subarnarekha, Mahanadi and Ajoy, which have immense importance in industrial and agricultural scenarios in eastern India. A distributed hydrological model (HECHMS) has been used on the four river basins using HadRM2 daily weather data for the period from 2041 to 2060 to predict the impact of climate change on water resources of these river systems.

Keywords: Climate change, water availability index, hydrological index, projected data, water resources, HECHMS model

\section{Introduction}

Water is a precious natural resource, which is vital for the life, health of people and ecosystem and a basic requirement for the development of a country and, at the same time, it is very complex to manage judiciously. Biswasroy et al., (2011) stated that the participation of each and every stakeholder is needed more, not only preserve or conserve the wetland, but also the biggest benefit of utilizing the water resource resulting emerging his or her life style and livelihood. The complexity has further increased on account of the possible impacts due to projected climate change. The hydrological cycle is likely to be altered due to climate change. Evidence shows that unprecedented changes in chemical composition of earth's atmosphere due to

Roy P.K., Samal N.R., Roy M.B. and Mazumdar A. (2015), Integrated assessment of impact of water resources of important river basins in Eastern India under projected climate conditions, Global NEST Journal, 17(3), 594-606. 
industrialization have the potential to influence hydrometeorology in the future (IPCC, 2001a and 2001b). Meteorological data compiled over the past century suggests that the earth is warming, but there are significant differences at regional levels. These differences might be due to climate change riding over natural climatic variability. Enhanced temperatures are expected to increase the mean sea level and disrupt the pattern of precipitation on both temporal and spatial scales. Intergovernmental panel on climate change (IPCC, 1990 and 1996) deals with the effect of global warming that would bring changes in annual average precipitation in the order of 20\% (Dodrecht, 1996). Hulme and Vinar (1995) projected greenhouse gas induced climate change scenario based on General Circulation Model (GCM) of Hadley centre for the year 2060 for tropical rain forests including those of Indian sub-continent. The projection is in terms of percentage changes in relevant parameters (from $10 \%$ to $70 \%$ over North, South, Central and North-East India) as compared to those of the year 1990s. On the other hand, Lal et al., (1995) using the European Community Hamburg (ECHAHA Version 3) model incorporating the effect of both greenhouse gas (GHG) and sulphate aerosol quoted a $10 \%$ change of precipitation in India as compared to the 1980 s. Although total land area comprises only about $3 \%$ of the world's land masses, population in 1990 was $21.3 \%$ of the global total and by 2025 ; it is expected to rise to $24 \%$. In 1980 the percentage of the population living in urban areas was $23 \%$ for India, $28 \%$ for Pakistan and 11\% for Bangladesh and by 2000 it had increased to 38\%, 37\% and 21\% respectively (Shukla et al., 2003).

In the Southeast Asian region, climatologically, India is situated in an important position, having very rich collection in flora and fauna. Changes to the present climate system may affect a variety of eco-systems, socioeconomic sector and industry in addition to water resources. Analysis, with long-term historic data shows increase as well as decrease in temperature and rainfall. However, there has been increase in annual temperature in the country as a whole. Climatic variability, in terms of rainfall and temperature, has noticeable spatial and temporal variations. In certain places, climatic extremes such as droughts, floods and timing of rainfall have also increased (Samal et al., 2014). The global mean annual temperature at the end of the 20th century is almost $0.7^{\circ} \mathrm{C}$ above the mean temperature recorded at the end of the 19th century (Karla et al., 2003). The extent of variability in the southwest and northeast monsoons leads to fluctuations in agricultural productivity around the trend line. Most of the studies during the last four decades clearly pointed out that monsoon rainfall is trend less and is mainly random in nature over a long period of time, particularly on all-India scale (Mooley and Parthasarathy, 1984). The analysis of historic data during 1871-1984 shows that areas of increasing trend in monsoonal rainfall are found along the west coast, north Andhra Pradesh and north-west India and those of a decreasing trend over east Madhya Pradesh and adjoining areas, northeast India and parts of Gujarat and Kerala (Rupa Kumar et al., 1992). Standardised Precipitation Index (SPI) and rainfall indices helps in understanding the climate change impacts and droughts. (Mundetia and Sharma, 2014). Analyses of historic weather data sets indicate rising temperature trends in most locations, with large year-to-year seasonal and annual variation around the trend line. Trends in pan evaporation ( $\left.E_{\text {pan }}\right)$ and temperature identified through the Mann-Kendall test over Jaisalmer in India showed simultaneous $E_{p a n}$ decrease and temperature rise which confirms the existence of evaporation paradox in the months of winter and post-monsoon seasons as a result of change in climatic condition. (Jhajharia et al., 2014).Thus, it is obvious from the studies in this area with rainfall and temperature that the understanding of the climatic variability is a difficult task (Shukla et al., 2003; Karla et al., 2003; Rupa Kumar et al., 2003). On one hand, climate change may further exacerbate the declining water availability to a great extent and on the other burgeoning population growth enhance the water requirement in agriculture, domestic and industrial sector considerably. Involving an adequate number of scientists from developing countries and to propose approaches to address the impact of climate change is the need of the hour (Singh and Patwardhan, 2014). The vulnerability and adaptive capacity of different societal groups and sectors to the impacts of climatic variability and change is essential for sustainable development in future (Jonsson et al., 2014). Local coping strategies and traditional knowledge need to be used in synergy with government and local interventions in 
order to modify the livelihood of people directly dependent on nature with respect to climate change (Kaushik and Sharma, 2015).

The present research is an attempt to use distributed hydrological modeling to quantify the future water availability of four important eastern river basins in India namely Damodar, Subarnarekha, Mahanadi and Ajoy. The river basins up to the outlet of the upper basin has been given the main emphasis for investigation because the water supply arrangement of the states like West Bengal, Jharkhand and Orissa are considerably dependent up to that part of the respective river basins. Thus the regions up to the outlet of the systems are especially vulnerable to potential changes in regional temperature and precipitation pattern.

\section{Materials and methods}

\subsection{Study area}

\section{Damodar River Basin}

Damodar River perhaps the most important sub basin of the Ganga-Brahmaputra-Meghna (GBM) basin since India's first largest river project is on this river. The Damodar river which lies between the latitudes $23^{\circ} 30^{\prime} \mathrm{N}$ and $24^{\circ} 19^{\prime} \mathrm{N}$ and longitudes $85^{\circ} 31^{\prime} \mathrm{E}$ and $87^{\circ} 21^{\prime} \mathrm{E}$, originates from the Palamu Hills of Chota Nagpur at an elevation of about $610 \mathrm{~m}$ above mean sea level. It flows in a southeasterly direction, entering the deltaic plains below Raniganj in Burdwan district, of West Bengal, India. Near Burdwan the river abruptly changes its course to southern direction and joins the Hughli River about $48 \mathrm{~km}$ below Kolkata. The slope during the first $241 \mathrm{~km}$ is about $1.89 \mathrm{~m}$ per km. During the next $161 \mathrm{~km}$ is about $0.57 \mathrm{~m}$ per $\mathrm{km}$, while the same is about 0.19 $\mathrm{m}$ per $\mathrm{km}$ in subsequent $145 \mathrm{~km}$. Six streams feed the river; the principal tributary, Barakar, joins the main river at Damodar where it emerges from the Palamu Hills. The four main multipurpose reservoirs located at Tilaiya, Konar, Maithon, Panchet and a Barrage at Durgapur, were commissioned during the period 19531959. Another tributary Khudia, whose catchment is neither intercepted by Maithon nor Panchet reservoirs, joins Damodar near its confluence with Barakar. This river with an uncontrolled catchment, sometimes contribute heavily at Durgapur Barrage during floods. In the plains the river splits into several channels, and ultimately joins the river Roopnarayan \& Hughli. The main channels, which presently carry most of the discharge, are Amta and Mundeswari channels. The total length of the river is about $541 \mathrm{~km}$. The total catchment area of the river is $28,015 \mathrm{~km}^{2}$, of which $26,015 \mathrm{~km}^{2}$ the catchment covers the region up to Durgapur Barrage, the outlet of the DVC system (DVC, 1990).

\section{Subarnarekha River Basin}

The Subarnarekha River Basin lies between longitudes $85^{\circ} 11^{\prime} \mathrm{E}$ and $87^{\circ} 21^{\prime} \mathrm{E}$ and latitudes $21^{\circ} 34^{\prime} \mathrm{N}$ and $23^{\circ} 18$ $\mathrm{N}$. The total catchment area is about $19,296 \mathrm{~km}^{2}$. There is one sub basin, which is Dulung sub-basin and the catchment area is $3404 \mathrm{~km}^{2}$. Sonakania being the outlet of the upper Subarnarekha catchment, it handles all the upstream runoff. In spite of handling such high volume of runoff, the model simulates the runoff quite effectively. That is why Sonakania has been chosen for comparing the observed and simulated runoff hydrograph for the projected years 2041-2060.

\section{Mahanadi River Basin}

The Mahanadi River Basin, a major Indian river basin, is located between longitudes $80^{\circ} 25^{\prime}$ and $87^{\circ} \mathrm{E}$ and latitudes $19^{\circ} 15^{\prime}$ and $23^{\circ} 35^{\prime} \mathrm{N}$. The total catchment area is about $141,589 \mathrm{~km}^{2}$. Two sub basins namely Dhenkanal and Cuttack sub catchments having areas $2945 \mathrm{~km}^{2}$ and $6393 \mathrm{~km}^{2}$ respectively are considered. Naraj being the outlet of the upper Mahanadi catchment, handles all the upstream runoff including those of the Dhenkanal and Cuttack sub catchments. That is why Naraj has been chosen for comparing the observed and simulated runoff hydrograph for the projected years 2041-2060. 


\section{Ajay River Basin}

The Ajoy river basin is situated between latitudes $23^{\circ} 50^{\prime} \mathrm{N}$ and $24^{\circ} 6^{\prime} \mathrm{N}$ and longitudes $86^{\circ} 16^{\prime} \mathrm{E}$ and $87^{\circ} \mathrm{E}$ and located in the plateau of Santhal Pargana. Two subbasins namely Jamtara in Jharkhand state and Natunhat in Birbhum district of West Bengal are considered. The Ajoy river emerges from forest covered hills of chakai block in Manager district of Bihar and flows over a length of $132 \mathrm{~km}$ in Jharkhand, enters West Bengal near Kalipahair and flows over a length $144 \mathrm{~km}$ over West Bengal and falls into Bhagirathi, which is a distributory emerging out of river Ganga, near Katwa. A number of small river lets like Kedhasa and Darwa join it at the upper reaches. The total basin area of the Ajoy River is $6,888 \mathrm{~km}^{2}$. The basin area in Jharkhand is $3,554 \mathrm{~km}^{2}$ which is $51.6 \%$ of the total basin area. In West Bengal, the basin area is $3,334 \mathrm{~km}^{2}$, which is $48.4 \%$ of the total. The basin area in Jharkhand is hilly whereas that in West Bengal is mostly plain. About $7 \%$ of the total area is under forest and about $63 \%$ are under cultivation.

\subsection{Data acquisition}

Pechlivanidis et al., (2011) stated that hydrological models are important for water resources planning, development and management. Their selection is usually based on data availability, spatial representation, computational cost, and model robustness. The HEC-HMS model (HEC-HMS, 2000 and 2001) requires data on hydrometeorology, soil, land-use, and weather assessment of water resource availability at the desired locations of the basin. The daily rainfall and streamflow data are used for the calibration and validation for river basins in India. The calibration is done based on sub-catchments for basins for all the projected years. The calibration error, expressed as a percent difference of simulated value with respect to observed value, is found to lie within the range of 0.2 to $20 \%$ (Roy and Mazumdar, 2005)

\subsection{Input data}

Soil and Land use Data- The following data have been used (i) Survey of India topographic sheets nos. 72D/12, $72 \mathrm{H} / 4,73 \mathrm{E} / 5,73 \mathrm{I} / 2,73 \mathrm{I} / 3$ and 79A/3 in 1:50,000 scale as collateral data (ii) Soil map from National Bureau of Soil Survey and Land Use Planning (NBSS \& LUP).

Weather data- Daily rainfall and discharge data for the last 43 years (January 1960 to December 2002) for five different sub-basins from Damodar Valley Corporation (DVC, 1970), West Bengal, India and for a period of twenty years (1971 to 1990) for the other three basins were used for the modeling study. The data generated in transient experiments by the "Hadley Centre for Climate Prediction" U.K., at a resolution $50 \mathrm{~km} \times 50 \mathrm{~km}$ of IITM, Pune. The daily weather data of maximum and minimum temperature, rainfall, solar radiation, wind speed and relative speed at all grid locations were processed. The Regional Climate Model (RCM) grid has been superimposed on the sub-basins for driving the weighted means of the inputs for each of the sub-basins. The centroid of each subbasin is then taken as the location for the weather station to be used in the HEC-HMS model. This procedure has been used for present/control (1971-2004) and future/GHG (2041-2060) climate data.

Weather future projection Data- Regional model of the Hadley Research Centre, UK HadRM2, is generating the climate scenario of mean monthly precipitation and temperature for 2041-2060. The formulation of HadRM2 is identical to the atmospheric component of HadCM2. The grid spacing in HadRM2 is $0.44^{0} \times 0.44^{0}$ ( $50 \times 50 \mathrm{~km})$, which is kept quasi-regular over the region of interest by shifting the coordinate pole.

\subsection{Modeling Technique}

HEC-HMS Package

The software Package HEC-HMS (Technical Reference Manual, 2000 and User's Manual, 2001) has been used for the simulation of runoff hydrograph in the Damodar basin. The HEC-HMS developed by Hydrologic Engineering Centre (HEC) of US Army Corps of Engineers is a well-known hydrologic model specially designed for the simulation of flood events in river basin. The package uses separate modules to represent each 
component of the runoff process. The precipitation losses are calculated for each computation time interval and are subtracted from the Mean Areal Precipitation (MAP) depth for that interval (Beven and Hornberger, 1982). The remaining depth is referred to as precipitation excess. This depth is considered uniformly distributed over a watershed area, so it represents a volume of runoff. In HEC-HMS, the transformation of rainfall excess to streamflow is accomplished by the unit hydrograph procedure $(\mathrm{NIH}, 1988-89$ and NERC, 1975). There are six unit hydrograph methods available in HEC-HMS, namely user-specified unit hydrograph, Clark's, Snyder's, SCS, Mod Clark and Kinematics Wave methods (Bhaskar et al., 1997; Maidment, 1992; Sherman, 1932 and Singh, 1988). However, Snyder's method is selected for the present study for the estimation of runoff. The Snyder method does not define a complete unit hydrograph, so the HEC-HMS program utilizes the Clark method in a trial-and-error procedure to complete the hydrograph. Initial Clark Parameters are derived from the Snyder parameters and these are used to compute a Clark unit hydrograph. A new set of Snyder parameters computed from this hydrograph is compared with the given Snyder parameters, and this process is continued for twenty iterations or until the difference between the computed and the given values is less than 1 percent.

The basic governing equation is

$$
\mathrm{T}_{\mathrm{p}}=\mathrm{C}_{\mathrm{t}} \times\left(\mathrm{L} \times \mathrm{L}_{\mathrm{ca}}\right)^{0.3}
$$

where $C_{t}, L$ and $L_{c a}$ denote regional constant representing watershed slope and storage, basin length measured along the water course from the basin divide to the gauging station in $\mathrm{km}$, and distance along the main course from the gauging station to a point opposite the watershed centroid in $\mathrm{km}$ respectively.

The Peak discharge per unit drainage area for rainfall excess of standard duration is computed as:

$$
Q_{p}=\frac{2.75 \times C_{p} \times A}{T_{p}}
$$

where $Q_{p}$ and $A$ represent peak discharge $\left(\mathrm{m}^{3} / \mathrm{s}\right)$ and basin area $\left(\mathrm{km}^{2}\right)$ respectively.

The standard duration of rainfall excess is a function of standard lag time and is given by

$$
\Delta \mathrm{t}=\frac{\mathrm{T}_{\mathrm{p}}}{5.5}
$$

where $\Delta t$ is the duration of rainfall excess in hours. To permit lag time and peak discharge to be computed for other unit hydrograph durations, the following equation is employed:

$$
\mathrm{T}_{\mathrm{pr}}=\mathrm{T}_{\mathrm{p}}+0.25 \times\left(\Delta \mathrm{t}_{\mathrm{r}}-\Delta \mathrm{t}\right)
$$

Where $T_{p r}$ is the adjusted lag time in hours and $\Delta t_{r}$ is new unit hydrograph duration in hours.

In HEC-HMS, the model of channel flow computes a downstream hydrograph, given an upstream hydrograph as a boundary condition. There are five routing methods available in HEC-HMS, namely Lag, Muskingum, Modified Puls, Kinematic Wave and Muskingum Cunge. However, the Muskingum method is selected for the present study for the estimation of the runoff on account of its capability to accommodate more complicated looped relationship of storage vs. outflow. In HEC-HMS, the model of channel flow computes a downstream hydrograph, given an upstream hydrograph as a boundary condition (Technical Reference Manual, 2000 and User's Manual, 2001).

The daily rainfall data and stream flow data for a period of forty-three years (January 1960 to December 2002) for the Damodar basin and for a period of twenty years (1971 to 1990) for the other basins such as Subarnarekha, Mahanadi and Ajoy basins were used for the calibration and validation. 
On account of paucity of space, the calibration for Durgapur, being the outlet of the DVC system of Damodar basin is shown by the stream flow hydrograph (Figs 1(a) and 1(b)) for the flood year 1978 and dry year 1988. The calibration error, expressed as a percent difference of simulated value with respect to observed value, were found to lie within the range of $0.2 \%$ to $20 \%$ for all the basins. However, it is worth to mention that the large river valley project like DVC with four reservoirs and one barrage makes the simulation of Damodar basins more challenging, as it becomes a controlled flow system. The reservoir regulations of each individual reservoir are taken into consideration while augmenting the flow volume.

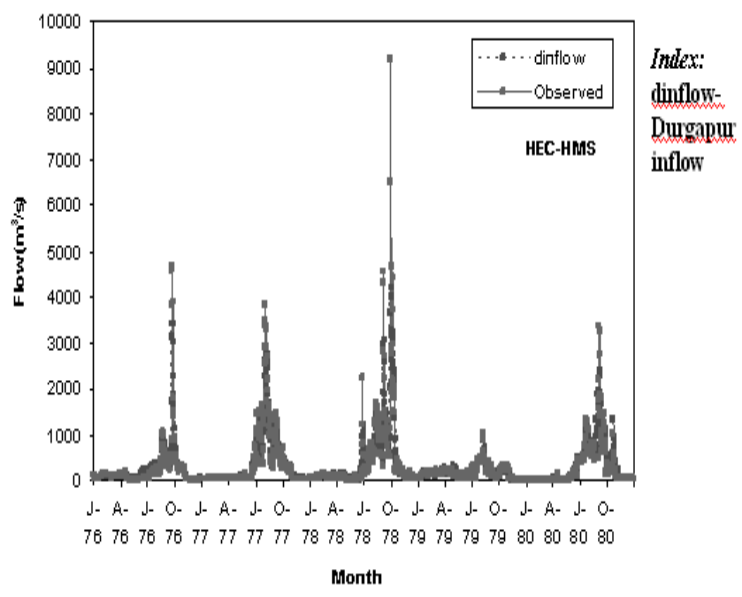

Figure 1(a). Simulated and observed hydrograph at Durgapur subcatchment for Damodar basin (1976-80

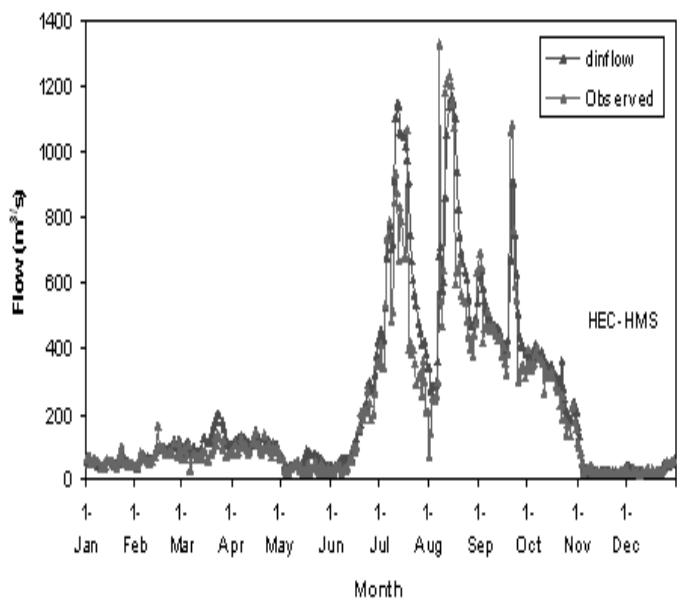

Figure 1(b). Simulated and observed streamflow at Durgapur subcatchment for Damodar basin (1988)

\section{Results and discussion}

\subsection{Water Resources Assessment}

In this present research work, the software Package HEC-HMS (Technical Reference Manual, 2000 and User's Manual, 2001) has been used for the simulation of runoff hydrograph for four important eastern river basins in India. In HEC-HMS the models of channel flow computes a downstream hydrograph, given an upstream hydrograph as a boundary condition. The daily rainfall data and stream flow data were used for the calibration and validation for four important eastern river basins in India. The calibration was done based on sub-basins for Damodar, Subarnarekha, Mahanadi and Ajoy basins for all the historical years (1960 to 2002 in case of Damodar river basin and 1971 to 1990 for other three river basins).

Analysis of the projected hydro meteorological data generated by Hadley Regional climate Model, HadeRM2 and that of the results simulated by the HEC-HMS model for a controlled flow system are estimated in the basin wise namely Damodar, Subarnarekha, Mahanadi and Ajoy river in eastern India. Changes in annual streamflow volume from basin average (1960-2002) are shown in Fig. 2 (a). The reduction in the streamflow volume is at a maximum in the Durgapur sub-catchment in the second decade. As expected the same trend of no changes in the annual stream flow volume of Subarnarekha river at Sonakania outlet point from historical basin average (1971-1990) has been observed during the projected years from 2041 to 2060 excepting the year 2059 (Fig. 2(b)). About 60\% reduction in stream flow volume at Naraj Outlet point from basin average (1971-1990) has been observed during ten out of twenty projected years. The annual stream 
flow volume reduced to about 70 to $75 \%$ of basin average during the remaining ten years (Fig. 2(c)). The only notable peak observed in the stream flow by hydrograph of 2054 lies in the low flood range of Mahanadi.

It can also be found that when high precipitation is observed, the correlation value of observed and simulated discharge is high $\left(R^{2}=0.8792\right)$. The monthly stream flow hydrographs depict a gradual shifting of the occurrence of peak flow from the month of September and August to the month of July and June for the projected years (Roy, 2006). The changes in annual stream flow volume have been found to be less than the basin average flow (1971-1990) in the projected years (Fig. 2(d)).

\subsection{Ganga-Damodar Basin}

Analysis is made over the entire Damodar basin but owing to paucity of space, the discussion of the results are made on the Durgapur subcatchment only as it is the outlet of the DVC flow system where the augmentation of runoff of all the sub-catchments are revealed through the hydrographs drawn at this point. The water availability in the basin under the changed climate scenario was evaluated using the projected daily precipitation \& mean monthly temperature data for 2041-2060 as supplied by Indian Institute of Tropical Meteorology (IITM), Pune. The following conclusions are drawn from the analysis:

The decreased river flow at Durgapur being the outlet of the DVC system, will ultimately affect the availability of water in the basin (Roy et al., 2004). Decreased peak flows will hinder natural flushing of stream channels leading to loss of carrying capacity and augment the sedimentation rate within the river system. In the event of an increase in the present rate of siltation of the reservoirs and channels, the dependability of the Damodar system may deteriorate. The surface water availability of the Damodar basin based on the population (GOI, Census, 2001) of 2001 was estimated in the tune of $989 \mathrm{~m}^{3} /$ capita/year whereas in the coming years, this may go down to a mean of $394 \mathrm{~m}^{3} /$ capita/year in the projected period of 2041-2060 considering the population growth as predicted by UN (1998).

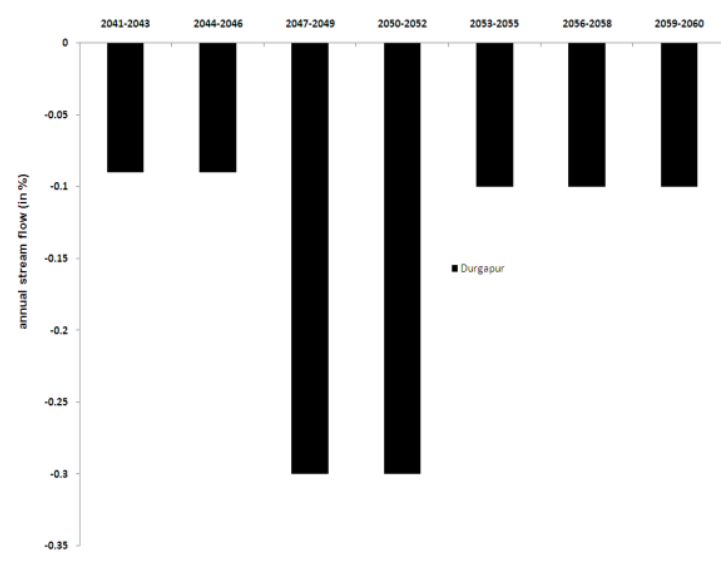

Figure 2(a). Deviation of annual stream flow from historical mean under changed climate scenario at Durgapur for Damodar river

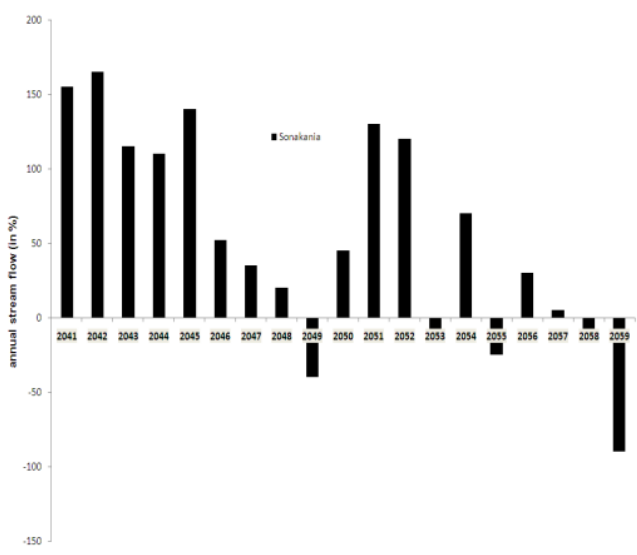

Figure 2(b). Deviation of annual stream flow from historical mean under changed climate scenario at Sonakania for Subarnarekha river 

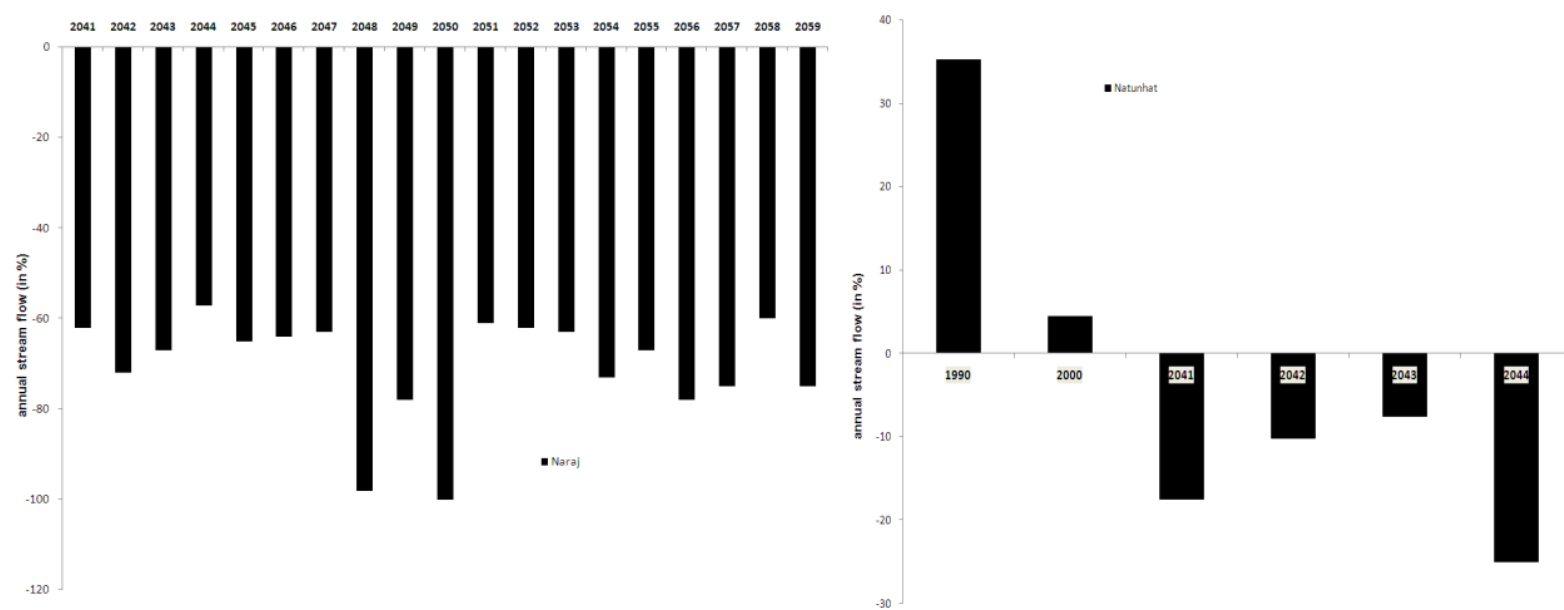

Figure 2(c). Deviation of Annual Stream Flow from Historical Mean Under Changed Climate Scenario at Naraj for Mahanadi river

Figure 2(d). Variation of annual stream flow over mean at Natunhat for Ajay river

\subsection{Subarnarekha and Mahanadi River Basin}

The surface water availability of the Subarnarekha basin based on the population (GOI, Census, 2001) of 2001 was estimated as $458 \mathrm{~m}^{3} /$ capita/year. However, this may go up to $749 \mathrm{~m}^{3} /$ capita/year in the projected periods (2040-60) considering the population projection as predicted by UN (1998). The surface water availability of the Mahanadi basin based on the population (GOI, Census, 2001) of 2001 was estimated as 1583 $\mathrm{m}^{3}$ /capita/year and this may even go down to $1039 \mathrm{~m}^{3} /$ capita/year in the projected periods (2010-40) considering the population projection as predicted by UN (1998).

\subsection{Ajay River Basin}

The water availability of the Ajay river basin based on the population (GOI, Census, 2001) of 2001 was estimated as $997 \mathrm{~m}^{3} /$ capita/year and this may go down to $468 \mathrm{~m}^{3} /$ capita/year in the projected periods (2040$60)$ considering the population projection as predicted by UN (1998). It may be concluded that for large depth of precipitation, the simulated results obtained by lumped approach and that by distributed approach marginally differs (Roy, 2006). However the lumped model fails to simulate the low-flows. Hence, floodforecasting studies involving high-flows may be simulated by lumped approach with reasonable accuracy and for both high and low flow simulation, distributed approach using SCS Curve Number (CN) and MuskingumCunge method proves to be equally effective. It may further be concluded that the future water availability at Natunhat will be reduced by about $15 \%$ for the first four occasions out of twenty projected years (20412060) and it is almost close to the basin average during the remaining years. Thus, the future per capita water availability for the Mahanadi and Ajoy river basins of eastern India will be reduced. The increasing population in the Damodar and Subarnarekha will cause the decrease in the per capita water availability in spite of unchanged streamflow volume predicted for future.

\subsection{Estimation of hydrological trends in all the four rivers}

In the present investigation, we have estimated the hydrological trends for all these four rivers by calculating the hydrologic response index (HRI) and the water availability index (WAI) as described in Table 1. 


\subsection{Hydrologic Response Index (HRI)}

In data sparse regions, development of a response index to hydrological parameters is a crucial issue to reduce uncertainty in hydrological prediction and to improve water resources management strategies (Youjing, 2009). Hydrologic Response Index is a measurement of degree of retention of water within a specific location. Higher value of $\mathrm{HRI}$ indicates low retention capability and lower value represents high retention capability of the specific location. HRI is calculated with the help of rainfall, area, average discharge and maximum discharge and is multiplied with a correction factor to convert it into the scale of study area and is represented as

$$
H R I=\frac{\left(\frac{\text { Runoff }}{\text { MaxRunoff }}\right)}{\left(\frac{\text { Rainfall }}{\text { MaxRainfall }}\right)} \frac{\text { unit }}{\text { sqkm }}
$$

$\mathrm{HRI}$ represent the present health of the catchment as retention is directly proportional to degree of healthiness of a basin. Hence, if a basin has a high HRI, it means the basin is degraded and cannot store water for agricultural use and for low HRI the catchment is capable of storing water.

\subsection{Water Availability Index (WAI)}

Water Availability Index represents the availability of remnant water per unit area after deduction of agricultural and industrial requirement from the total available water. WAl is a function of discharge, rainfall, area and non-agricultural consumption of water. Higher the WAI, lower is the water available after the agricultural and industrial use. If a large amount of water in an area remains unused, then the area is not under water stress but the opposite will imply dryness in the region. WAI is a fine index for the measurement of water stress in an area and also helps to calculate the amount of virtual water, which again describes the industrial readability of an area. Meigh et al., (1999) took in their GWAVA (Global Water Availability Assessment) model the temporal variability of water availability into account. The index includes surface water as well as groundwater resources, and compares the total amount to the demands of all sectors, i.e. domestic, industrial and agricultural demands. The month with the maximum deficit or minimum surplus respectively is decisive. The index is normalised to the range -1 to +1 . When the index is zero, availability and demands are equal.

WAI $=\frac{R+G-D}{R+G+D}$ with $R=$ surface runoff, $G=$ groundwater resources and $D=$ sum of demands of all sectors.

Table 1. WAI and HRI for the River Basins during the years 2041, 2051, 2060

\begin{tabular}{|c|c|c|c|c|c|c|c|c|}
\hline \multirow[b]{2}{*}{ Year } & \multicolumn{2}{|c|}{ Damodar } & \multicolumn{2}{|c|}{ Ajoy } & \multicolumn{2}{|c|}{ Subarnarekha } & \multicolumn{2}{|c|}{ Mahanadi } \\
\hline & WAI & Water Stress & WAI & Water Stress & WAI & Water Stress & WAI & Water Stress \\
\hline 2041 & 0.998 & Yes & 0.996 & Yes & 0.997 & Yes & 0.398 & Yes \\
\hline 2051 & 1 & No & 1 & No & 1 & No & 1 & No \\
\hline 2060 & 1 & No & 1 & No & 1 & No & 1 & No \\
\hline & & Hydrological & & Hydrological & & Hydrological & & Hydrological \\
\hline Year & HRI & Stress & HRI & Stress & HRI & Stress & HRI & Stress \\
\hline 2041 & 0.548 & Yes & 0.489 & Yes & 1.382 & No & 1.643 & No \\
\hline 2051 & 0.437 & Yes & 0.473 & Yes & 0.685 & Yes & 0.523 & Yes \\
\hline 2060 & 0.393 & Yes & 0.412 & Yes & 0.596 & Yes & 0.512 & Yes \\
\hline
\end{tabular}


The surface water availability is calculated as the $90 \%$ reliable runoff. The groundwater availability is estimated either as the potential recharge that is calculated from the monthly surface water balance (Gleick, 1987), or as the potential aquifer yield.

\subsection{Future Vulnerabilities}

\subsubsection{Hydrologic \& Water Stress}

$\mathrm{HRI}$ and WAI is a good measure of hydrologic and water stress. According to Table 1, River Damodar will be on hydrological stress i.e. the catchment will degrade and the basin will be unable to store the water in 2041. The stress will decrease in 2050 and 2060. According to WAl, the river basin will face severe water stress during 2040-60 and will be in shortage of water. But the basin shows no sign of water shortage except in Durgapur.As Durgapur is a densely populated industrial as well as agricultural zone and as the industry is estimated to grow at a rate of $20 \%$ and population at a rate of $25 \%$; the prediction seems to be showing the reality. In case of River Ajay, only the outlet is in hydrologic stress for the year 2040 and in 2050 and 2060, both subbasin and outlet will be under stress.

\section{Conclusions}

Climate change is posing a serious challenge to the existing water resources in India for that matter hydrological studies are required to be undertaken up for assessment of water resources under changed climatic conditions. The reduction in the streamflow volume is at a maximum in the Durgapur sub-catchment in the second decade. As expected the same trend of no changes in the annual stream flow volume of Subarnarekha river at Sonakania outlet point from historical basin average has been observed during the projected years from 2041 to 2060 excepting the year 2059. About $60 \%$ reduction in stream flow volume at Naraj Outlet point from basin average has been observed during ten out of twenty projected years. The annual stream flow volume reduced to about 70 to $75 \%$ of basin average during the remaining ten years. The only notable peak observed in the stream flow by hydrograph of 2054 lies in the low flood range of Mahanadi. The monthly stream flow hydrographs depict a gradual shifting of the occurrence of peak flow from the month of September and August to the month of July and June for the projected years. The changes in annual stream flow volume have been found to be less than the average flow in the projected years. Pechlivanidis et. al., (2015) also found that the impact of climate change on the hydro-climatology of the Luni River in India, based on the CORDEX-South-Asia framework and bias-corrected using the DBS method before being entered into the HYPE (Hydrological Predictions for the Environment) hydrological model region showed $- \pm 20 \%$ change in the long-term average precipitation and evapo-transpiration, whereas more pronounced impacts i.e. $\pm 40 \%$ change are expected for runoff.

The surface water availability of the Subarnarekha basin based on the population (GOI, Census, 2001) of 2001 was estimated as $458 \mathrm{~m}^{3} / \mathrm{capita} /$ year. However, this may go up to $749 \mathrm{~m}^{3} /$ capita/year in the projected periods (2040-60) considering the population projection as predicted by UN (1998). The surface water availability of the Mahanadi basin based on the population (GOI, Census, 2001) of 2001 was estimated as 1583 $\mathrm{m}^{3}$ /capita/year and this may even go down to $1039 \mathrm{~m}^{3} /$ capita/year in the projected periods (2010-40) considering the population projection as predicted by UN (1998). For proper prediction of the future scenario of future water availability, the model needs to be calibrated with past diurnal hydrological data (i.e. rainfall, temperature and discharge). But the extensive hydrological simulation is required over the total basin instead of an isolated sub basin of the respective basins and the runoff hydrographs clearly depict that in spite of lack of data as regards the soil characteristics slope and also the land use pattern, the efficacy of the model in simulating the runoff is of high order. It is imperative to say that the availability of hourly rainfall data would simulate the flood peak more accurately. The water availability of the Ajay river basin based on the population (GOI, Census, 2001) of 2001 was estimated as $997 \mathrm{~m}^{3} /$ capita/year and this may go down to 468 
$\mathrm{m}^{3}$ /capita/year in the projected periods (2040-60) considering the population projection as predicted by UN (1998).

It may be concluded that for large depth of precipitation, the simulated results obtained by lumped approach and that by distributed approach marginally differs. However the lumped model fails to simulate the lowflows. Hence, flood-forecasting studies involving high-flows may be simulated by lumped approach with reasonable accuracy and for both high and low flow simulation, distributed approach using SCS Curve Number (CN) and Muskingum-Cunge method proves to be equally effective. It may further be concluded that the future water availability at Natunhat will be reduced by about $15 \%$ for the first four occasions out of twenty projected years (2041-2060) and it is almost close to the basin average during the remaining years. HRI and WAl is a good measure of hydrologic and water stress. River Damodar will be on hydrological stress i.e. the catchment will degrade and the basin will be unable to store the water in 2041. The stress will decrease in 2050 and 2060. According to WAl, the river basin will face severe water stress during 2040-60 and will be in shortage of water. But the basin shows no sign of water shortage except in Durgapur. As Durgapur is a densely populated industrial as well as agricultural zone and as the industry is estimated to grow at a rate of $20 \%$ and population at a rate of $25 \%$; the prediction seems to be showing the reality. In case of River Ajay, only the outlet is in hydrologic stress for the year 2040 and in 2050 and 2060, both sub-basins and outlet will be under stress.

\section{Acknowledgement}

The author expresses their sincere thanks to NATCOM Project: MoEF, GOI/UNDP-GEF/Winrock International India for providing initial financial support to carry out the initial work. The author acknowledges the reviewers of this paper, Dr. Illias lordanidis and Dr. Illias Pechlivanidis for their contribution to improve the quality of paper.

\section{References}

Beven K.J. and Hornberger G.M. (1982), Assessing the effect of spatial pattern of precipitation in modeling stream flow hydrographs, Water Resources Bulletin, 823-829.

Bhaskar N.R., Parida B.P. and Nayak A.K. (1997), Flood Estimation for ungauged Catchments using the GIUH, Journal of Water Resources Planning and Management, 123(4), 228-238.

Biswasroy M., Samal N.R., Roy P.K. and Mazumdar A. (2011), Watershed Management with Special Emphasis on Fresh Water Wetland: A Case Study of a Flood Plain Wetland in West Bengal, India, Global NEST Journal, 13(1), 1-10.

Damodar Valley Corporation (DVC). (1990) Proc. Workshop on water quality management for Damodar river System (Damodar Action Plan), Calcutta.

Dordrecht, (1996) Climate Change 1995: Impacts, Adaptations and Mitigation under Climate Change (ed.): ScientificTechnical Analysis, IPCC, Academic Publishers, Netherlands.

Gleick P.H. (1987), The development and testing of a water-balance model for climate impact assessment: modeling the Sacramento Basin, Water Resour. Res., 23, 1049-1061.

GOI (Government of India) (1991-2001) Census of India, 2001.

HEC-HMS, Version 2.2.2. (2000) Hydrologic Simulation Package, Technical Reference Manual, US Army Corps of Engineers, Hydrologic Engineering Centre

HEC-HMS, Version 2.2.2. (2001) Hydrologic Simulation Package, user's Manual, US Army Corps of Engineers, Hydrologic Engineering Centre.

Hulme M. and Viner D. (1995), A climate change scenario for assessing the impact of climate change on tropical rain forests, Climate Change Unit (East Anglia, U.K.) for WWF, USA.

IPCC (1990) Climate Change: the IPCC Scientific Assessment. J.T.Houghton, G.J. Jenkins, and J.J. Ephraums (eds), Cambridge University Press, Cambridge, United Kingdom 
IPCC (1996) Climate change 1995: Impacts, Adaptations and Mitigation under Climate Change: Scientific-Technical Analysis, Contribution of Working Group II to second report of the Intergovernmental Panel on Climate Change. Ron Benioff editor, Kluwer Academic Publishers, The Netherlands

IPCC (2001a) Climate Change 2001: The Scientific Basis. Contribution of Working Group I to the Third Assessment Report of the Intergovernmental Panel on Climate Change (IPCC), Cambridge University Press, Cambridge, UK.

IPCC (2001b)Climate Change 2001: Impacts, Adaptation \& Vulnerability. Contribution of Working Group II to the Third Assessment Report of the Intergovernmental Panel on Climate Change (IPCC), Cambridge University Press, Cambridge, UK.

Jhajharia D., Singh V.P., Kumar R. and Choudhary R.R. (2015), Searching evidence for the existence of evaporation paradox in arid environments of northwest India, Global NEST Journal, 17, 1, 3-11.

Jonsson A.C., Rydhagen B., Wilk J., Feroz A.R., Rani A. and Kumar A. (2015), Climate change adaptation in urban India: the inclusive formulation of local adaptation strategies, Global NEST Journal, 17, 1, 61-71.

Karla N., Aggarwal P.K., Chander S., Pathak H., Choudhary R., Choudhary A., Sehgal M., Raj H.K., Soni U.A., Sharma A., Jolly M., Singh U.K., Ahmed O. and Hussain M. Z. (2003), Impacts of climate change on agriculture. In: Climate Change and India: Vulnerability Assessment and Adaptation, Universities Press, Hyderabad, India.

Kaushik G. and Sharma K.C. (2015), Climate change and rural livelihoods-adaptation and vulnerability in Rajasthan, Global NEST Journal, 17, 1, 41-49.

Lal M., Cubasch U., Vass R. and Waszkewitz J. (1995), Effect of transient increase in greenhouse gases and sulphate aerosols on monsoon climate, Current Sci. J., 69, 752-763.

Maidment, D.R., (Edited) 1992. Handbook of Hydrology, Chapter 9, McGraw Hill, New York.

Meigh J.R., Mekenzie A.A. and Sene K.J. (1999), A grid-based approach to water scarcity estimates for eastern and southern Africa, Water Resour. Manage., 13, 85-113.

Mooley D.A. and Parthasarathy B. (1984), Fluctuations of all-India summer monsoon rainfall during 1871-1978, Climate Change, 6, 287-301.

Mundetia N. and Sharma D. (2015), Analysis of rainfall and drought in Rajasthan state, India, Global NEST Journal, $17,1,12-21$.

National Environment Research Council, (1975) Flood Studies Report, Vol. III, Flood Routing Studies, Institute of Hydrology, Wallingford, England.

National Institute of Hydrology, (1988-89). Flood Estimation by Unit Hydrograph Techniques, Workshop Course Material, Roorkee.

Noguer M., Jones R.H., Hassel D., Hudson D., Wilson S., Jenkins G. and Mitchell J.F.B. (2002) Workbook on Generating High Resolution Climate Change Scenarios using PRECIS. Hadley Centre for Climate Prediction and Research, Met Office, Bracknell, UK.

Pechlivanidis I.G., Jackson B.M., Mcintyre N.R. and Wheater H.S. (2011), Catchment scale hydrological modelling: a review of model pes, calibration approaches and uncertainty analysis method in the context of recent developments in technology and applications, Global NEST Journal, 13(3), 193-214.

Pechlivanidis I.G., Olsson J., Sharma D., Bosshard T. and Sharma K.C. (2015), Assessment of the climate change impacts on the water resources of the Luni region, India, Global NEST Journal, 17(1), 29-40.

Roy P.K. (2006) Prediction of Water Resources of Some Important Eastern River Basins on account of Global Climate Change with the help of Hydrologic Simulation Mode. Ph.D. thesis awarded in the School of Water Resources Engineering, Jadavpur University, Kolkata, India

Roy P.K., Roy D. and Mazumdar A. (2004), An Impact Assessment of Climate Change and Water Resources Availability of Damodar River Basin, Hydrology Journal, 27(3-4), 53-70.

Rupa Kumar K., Kumar K., Prasanna V., Kamala K., Desphnade N.R., Patwardhan S.K. and Pant G.B. (2003), Future climate scenario. In: Climate Change and India: Vulnerability Assessment and Adaptation, Universities Press, Hyderabad, India. 
Rupa Kumar K., Pant G.B., Parthasarathy B. and Sontakke N.A. (1992), Spatial and subseasonal patterns of the long-term trends of Indian summer monsoon rainfall, International Journal of Climatology, 12, 257-268.

Samal N.R., Roy P.K., Majumadar M., Bhattacharya S. and Biswasroy M. (2014), Six Years Major Historical Urban Floods in West Bengal State in India: Comparative Analysis Using Neuro-Genetic Model, American Journal of Water Resources, 2(2), 41-53, DOI:10.12691/ajwr-2-2-3

Sherman L.K. (1932). Stream Flow from Rainfall by the Unit-Graph Method", Eng. News-Rec., 108, 501- 505.

Shukla P.R., Sharma S.K., Garg A., Bhattacharya S. and Ravindranath N.H. (2003), Climate change vulnerability assessment and adaptation: the context. In: Climate Change and India: Vulnerability Assessment and Adaptation, Universities Press, Hyderabad, India.

Singh A. and Patwardhan A. (2014), Assessing the effects of participation in IPCC: implications in capacity building of scientists from developing nations in research for adaptation and mitigation, Global NEST Journal, 17(1), 22-28.

Singh V.P. (1988). Hydrologic Systems Rainfall-Runoff Modeling, Vol.1, Chapter 10, Prentice Hall, New Jersey.

United Nations (UN). (1998) World Population Prospect: The 1998 Revision, Vol.I, Sales No. E99XIII.9.

Youjing Z., Bo C., and Chuan H. (2009). Development of a Hydrological Response Index to Represent TOPMODEL Parameters, Joint International Convention of $8^{\text {th }}$ IAHS Scientific Assembly and $37^{\text {th }}$ IAH Congress Water: A vital resource under stress - How Science can help September 6-12, 2009, Hyderabad, India. 